\title{
韓国農村地域老人の日常生活動作能力の実態とその関連要因
}

李 起男* 李 誠国**

\section{A Study on Activities of Daily Living and the Related Factors in Korean Rural Elderlies}

\author{
Ki-Nam LEE* and Sung-Kook LEE**
}

In order to assess activities of daily living (ADL) and instrumental activities of daily living (IADL) in Korean rural elderlies and to investigate the related factors, we surveyed 705 elderly persons (277 males and 428 females) aged 60 years and over living in fourteen villages of Gang-dong Myon, a rural area in Kyung-Ju County of Kyung Sang Prefecture. They were interviewed by 18 trained health workers using the questionnaire from 3 to 10 July in 1995. The results were as follows:

1) The prevalence of disability in ADL ranged from $0.7 \%$ in eating to $6.5 \%$ in incontinence and significantly increased with aging for all 6 items, both for males and females. The prevalence was higher for males than females except "incontinence".

2) The prevalence of disability in IADL ranged from $11.4 \%$ in preparing meals to $21.4 \%$ in managing deposits and increased significantly with aging for all 5 items, both for males and females. The prevalence was higher for females than males except "preparing meals".

3) In the results of stepwise multiple regression analyses of ADL and IADL as the dependent factor, the most contributing factors for ADL were age, health status, and leisure time, and those for IADL were age, living expenses, ADL, family type, job, and leisure time.

Key words : ALD, IADL, rual elderly ADL，IADL，農村老人

\section{I はじめに}

韓国は1960年代初めより本格的な経済開発に取 り組み，ここ30年余りの間に近代経済成長を達成 し，経済社会の近代化を推し進めてきた。その結
果, 生活水準, 公衆衛生の改善により, 平均寿命 の伸びは著しい.

1960 年の韓国人の平均寿命は男性 53.0 年，女性 57.8 年だったが, 1990年には男性67.4年,女性 75.4 年であり,この 30 年間に男性は 14.3 年,女性は 17.6

$*$ 園光大学校漢医科大学

** 慶北大学校医科大学

* School of Oriental Medicine, Wonkang University

** School of Medicine, Kyungpook National University 
年も伸びている，一方，1960年代初めの経済開発 と同時に，家族計画を広範に実施し，人口増加の 抑制を行ってきた。その努力が実り, 出生力の低 下にともない，人口増加率が低下し，また，その 過程において, 人口高齢化が進行してきた。韓国 の65歳以上の老人人口が総人口に占める割合は 1960年は3.2\%であったが1994年には $5.8 \%$ とな り, 2000年以後はさらに加速し,2020年には $12.5 \%$ と予測されている.

しかしながら, 死亡率に基づいて算出した平均 寿命のみでは, 高齢者の健康状態や日常の活動を 正確に表すには不十分である.WHO の老化の疫 学に関する専門委員会 (WHO，1984）は，老人の 場合, 生活機能の自律性 (autonomy) を健康度の 指標とするのが有効であるとしている．Lawton ら (Lawton and Brody, 1969 ; Lawton, 1972) は, 人間の活動能力を 7 段階の水準で体系化した. つまり，1）生命維持 (life maintenance), 2) 機 能的健康度 (functional health), 3) 知賞-認識 (perception-cognition), 4) 身体的自立 (physical self-maintenance)，5）手段的自立 (instrumental self-maintenance)，6）状況対応 (effectance), 7）社会的役割（social role）に分類した.

Katz et al. (1983) の日常生活動作能力 (Activities of Daily Living: ADL) 指標は, Lawton (1972)の人間の活動能力の 7 段階中第 4 段階に当 たる “身体的自立維持能力” の程度を測定したも のである.ADL の尺度は老人一般の健康状態の客 観的指標として, 慢性疾患患者の治療の効果を測 る手段として，また地域社会における福祉・医療 サービスのニーズ把握の手段として, その適用範 囲は広がっている。

さらに，古谷野ら（1987）は地域で独立して生 活をするために必要な活動能力に関する尺度とし て, Lawton の活動能力の体系に準拠し, 老研式活 動能力指標の手段的 ADL (Instrumental Activities of Daily Living : IADL) を新しく開発した. IADL は, Lawton (1972) の人間の活動能力の 7 段階中，第 5 段階に相当する “手段的自立維持能 力”の程度を測定したのであり, Fillenbaum
（1985）も支持するように，老人が在宅で独立して 生活する（ひとりでも生活できる）ことに必要な 能力を評価することを目的としている.

本論文は，韓国の農村地域に居住している在宅 老人の ADL と IADL の実態とその関連要因を調 查し, 韓国老人の生活活動能力を判断することを 目標としている。

\section{II 調査対象と調査時期}

本研究の調査対象は, 韓国の慶尚北道・慶州市 管内江東面（27里）のうち，1つの保健支所と 1 つの保健診療所が管轄している14里に居住する満 60 歳以上の在宅老人 705 人全員である。なお，本調 查は1995年 7 月 3 日から 1 週間行ったが，その 2 週間前に実施した予備調査で, 調查票の信頼性, 調査員の面接技法の調整など調査の精度・再現性 を高める配慮を行った。予備調査の対象は本調査 対象者の中の 50 名（男性25名，女性25名）であっ た。

\section{III 調査方法}

調查方法として, 日常生活動作能力 (ADL) は Katz et al. (1970) が考案した 6 項目，および手 段的 ADL（IADL）は日本の老研式活動能力指標 で古谷野ら（1987）が考案した 5 項目を用いた。 設問内容は “はい”か “いいえ”で回答するため， “はい”は 1 点，“いいえ”は 0 点とし，ADLは 6 点満点, IADL は 5 点満点とした（図 1).

ADL と IADL に関連があると思われる一般的 属性として, 性, 年齢, 学歴, 仕事, 宗教, 配偶 者との同居の有無, 家族構成, 現在の疾患の有無, 主観的健康状態，生活費負担，余㗇時間の活用の 有無を調査した。

資料収集は調査地域の保健指導員 18 人を調査員 として， あらかじめ設問内容を十分説明した後， 老人に訪問面接して行った。

\section{IV 結 果}

\section{1. 対象者の概要}

調査した老人は 705 人で, 男性が 277 人 (39.3\%)， 


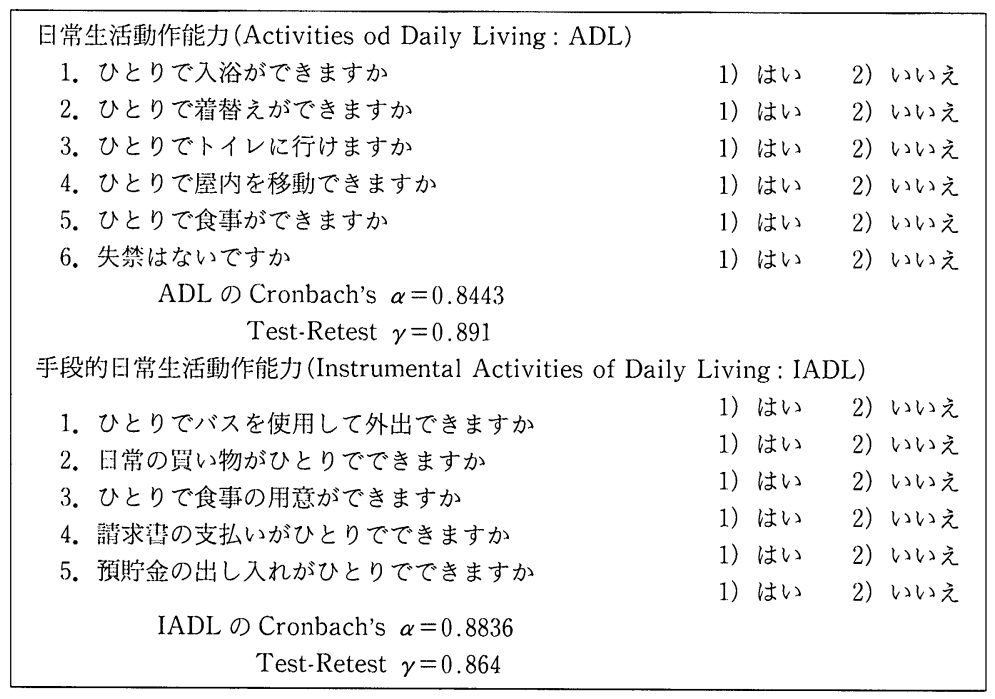

図 1 日常生活動作能力（ADL）と手段的日常生活動作能力（IADL）の項目

女性が428人 $(60.7 \%)$ であった。年齢は60歳から 95歳で, 平均70.4歳であり, 60歳代が男性で $55.2 \%$ ，女性で53.3\%を占めていた。

学歴は男性が無修学 $55.2 \%$, 女性が無修学 $82.4 \%$ であり,仕事は男性の $84.7 \%$,女性の $63.5 \%$ が農業であった。宗教は男性の $61.4 \%$ ，女性の $67.3 \%$ が仏教であり, 配偶者“あり”は男性が 84.1\%，女性が40.7\%であった。

家族構成でひとり暮らしは男性が $3.6 \%$,女性が $24.3 \%$ であり，子供と同居は男性が $49.5 \%$ ，女性 が51.4\%であった。現在の疾患が “ある”は男性 が44.4\%，女性が59.1\%であった。

生活費負担については子供に完全に依存してい る男性は $47.7 \%$ ，女性は $36.4 \%$ あ゙り，余暇時間 (hobby and leisure) の有無については男性は $24.2 \%$ ，女性は $10.3 \%$ が持っていると答えた。主 観的健康状態が “よい”男性は $39.4 \%$, 女性は $30.4 \%$ であった。

日常生活動作能力（ADL）については 6 項目す べてをできない男性は $0.4 \%$ ( 1 人)，女性は $0.5 \%$ （2人)であり，すべてできる男性は $90.3 \% ， 女$ 性 は91.1\%であった。

手段的 $\mathrm{ADL}$ (IADL) については 5 項目すべて
をできない男性は $9.8 \%$ ，女性は $5.8 \%$ であり，す べてできる男性は $79.8 \%$ ，女性は $72.4 \%$ でった (表 1 ).

\section{2. 性・年齢の ADL の障害頻度}

性・年齢別の日常生活動作能力 (ADL) 障害の 頻度は, “失禁する”が $6.5 \%$ で一番高く, 次いで “入浴”, “着替え”, “歩行”, “B トイレの使用”, “食事”の順であった。すべての項目について加跲 とともに障害頻度が高くなる傾向がみられた。性 別に障害の割合を比較すると，“食事”の項目で女 性が多かったが，それ以外の項目では男性のほう が多かった（表 2 ).

性・年歯別の ADL 評点については, 高 ADL ( 6 点) は男性が 250 人 ( $90.2 \%)$,女性が390人 ( $91.1 \%)$ であり, 中 $\mathrm{ADL}(1 \sim 5$ 点) は男性が 26 人 (9.4\%), 女性 36 人 (8.4\%) であり, 低 ADL（0点）は男 性が 1 人 $(0.4 \%)$ ，女性が 2 人 $(0.5 \%)$ であった (表 3 ).80歳以上になると男女共に高得点者は急 減しており，女性よりも男性の落ち込みが目立つ が男女での有意差はなかった（表 6 ）。

\section{3. 性・年齢別の IADL の項目別障害頻度}

1) IADL の 5 項目別の障害頻度

年齢別の手段的 ADL（IADL）障害頻度につい 
表 1 調査対象老人の属性と ADL, IADL

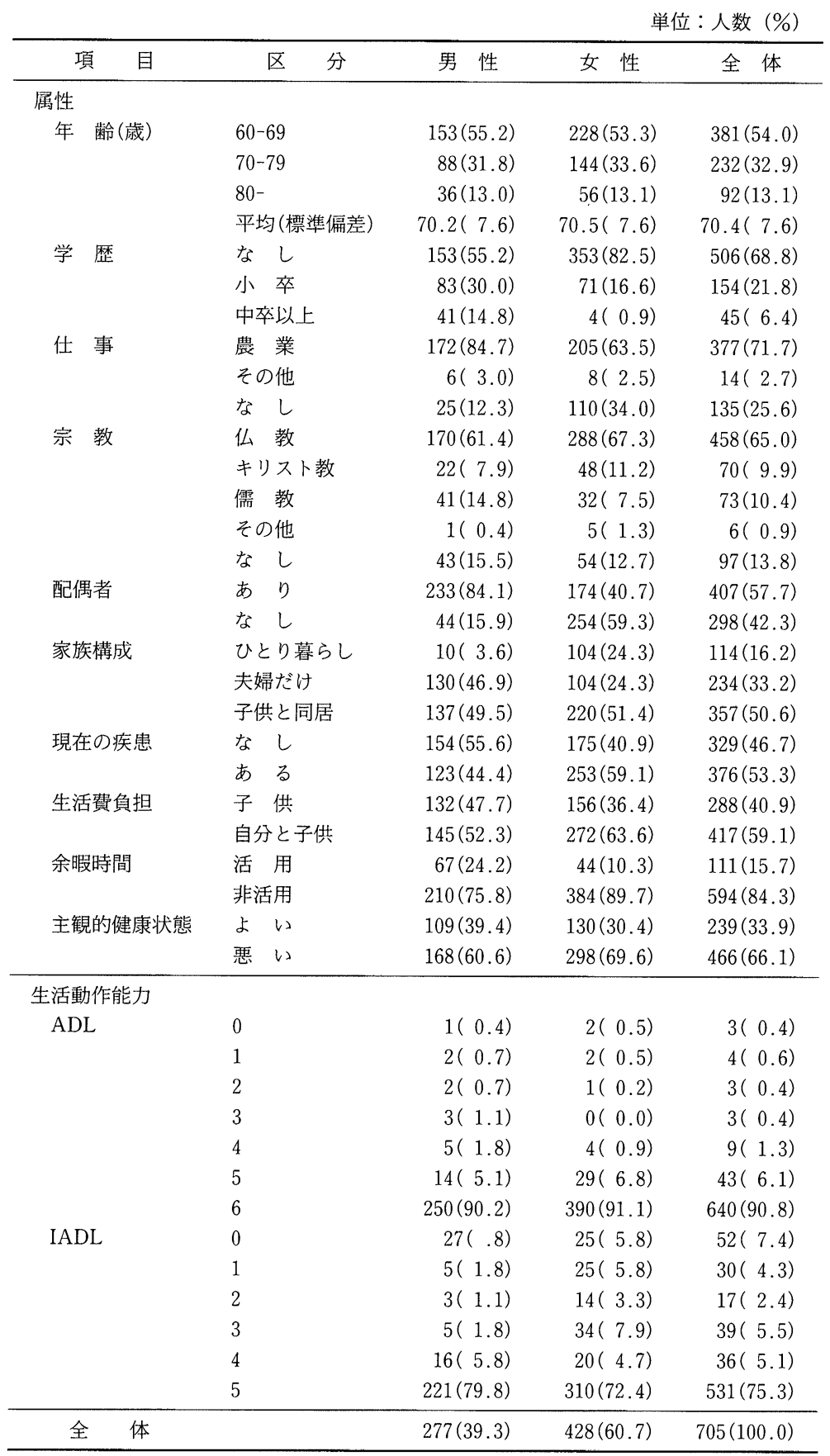


表 $2 \mathrm{ADL}$ の項目別性・年齡別障害頻度

\begin{tabular}{|c|c|c|c|c|c|c|}
\hline \multirow{2}{*}{ 年歯俞 (葴) } & \multicolumn{3}{|c|}{ 入 } & \multicolumn{3}{|c|}{ 着 } \\
\hline & 男 性 & 女 性 & 全 体 & 男 性 & 女 性 & 全 体 \\
\hline $60 \sim 69$ & $6(3.9)$ & $2(0.9)$ & $8(2.1)$ & $2(1.3)$ & $2(0.9)$ & $4(1.1)$ \\
\hline $70 \sim 79$ & $2(2.3)$ & $5(3.5)$ & $7(3.2)$ & $1(1.1)$ & $2(1.4)$ & $3(1.3)$ \\
\hline $80 \sim$ & $8(22.2)$ & $10(17.9)$ & $18(19.6)$ & $5(13.9)$ & $3(5.4)$ & $8(8.7)$ \\
\hline 全 体 & $16(5.8)$ & $17(4.0)$ & $33(4.7)$ & $8(2.9)$ & $7(1.6)$ & $15(2.1)$ \\
\hline \multirow{2}{*}{ 年秚令(歳) } & \multicolumn{3}{|c|}{ トイレの利用 } & \multicolumn{2}{|c|}{ 歩 } & \\
\hline & 男 性 & 女 性 & 全 体 & 男 性 & 女 性 & 全 体 \\
\hline $60 \sim 69$ & $0(0.0)$ & $2(0.9)$ & $2(0.5)$ & $1(0.7)$ & $3(1.3)$ & $4(1.1)$ \\
\hline $70 \sim 79$ & $1(1.1)$ & $1(0.7)$ & $2(0.9)$ & $0(0.0)$ & $1(0.7)$ & $1(0.4)$ \\
\hline $80 \sim$ & $4(11.1)$ & $2(3.6)$ & $6(6.5)$ & $4(11.1)$ & $2(3.6)$ & $6(6.5)$ \\
\hline 全 体 & $5(1.8)$ & $5(1.2)$ & $10(1.4)$ & $5(1.8)$ & $6(1.4)$ & $11(1.6)$ \\
\hline \multirow{2}{*}{ 年藏令 (歳) } & \multicolumn{3}{|c|}{ 食 } & \multicolumn{2}{|c|}{ 失 } & \\
\hline & 男 性 & 女 性 & 全 体 & 男 性 & 女 性 & 全 体 \\
\hline $60 \sim 69$ & $0(0.0)$ & $1(0.4)$ & $1(0.3)$ & $8(5.2)$ & $11(4.8)$ & $19(5.0)$ \\
\hline $70 \sim 79$ & $0(0.0)$ & $0(0.0)$ & $0(0.0)$ & $4(4.6)$ & $6(4.2)$ & $10(4.3)$ \\
\hline $80 \sim$ & $1(2.8)$ & $3(5.4)$ & $4(4.4)$ & $10(27.8)$ & $7(12.5)$ & $17(18.5)$ \\
\hline 全 体 & $1(0.4)$ & $4(0.9)$ & $5(0.7)$ & $22(2.9)$ & $24(5.6)$ & $46(6.5)$ \\
\hline
\end{tabular}

表 $3 \mathrm{ADL}$ 評点の性・年齢別頻度

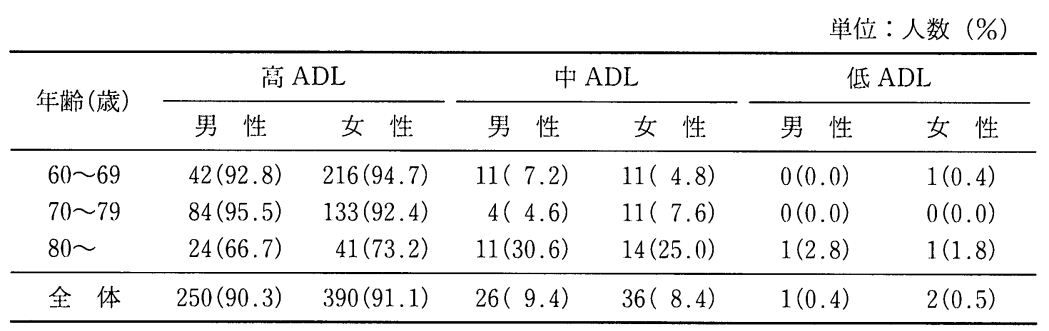

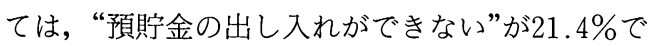
最も高率で，すべての項目について加齢にとも なって障害頻度が高率になった。 また, 性別比較 では“自分で食事の用意ができない”が男性で 17.7\%，女性は7.2\%であり，唯一男性が女性より も高率であったが, その他の項目では女性の障害 頻度が高率であった（表 4 ）。この結果は ADLの 場合と逆になっていた。

2) IADL の総評点の頻度

性・年柃別における IADL の分布を見ると，高 IADL（5 点）は男性が 221 人 (79.8\%), 女性が 310 人 $(72.4 \%)$ であり, 中 IADL (1〜4点) は男性
が29人 (10.5\%)，女性 93 人 (21.7\%) であり，低 IADL（ 0 点）は男性が 27 人 ( $9.8 \%)$ ，女性が25人 (5.8\%)であった(表 5 ). IADL では，ADLに比 べて70歳代で早くも低下が目立ち, 80歳以上では, さらに顕著に低下していた。なお，男女差では女 性の方で低下が顕著であった。ただし，男女差は 統計的に有意ではなかった（表 7 ）。

\section{4. 属性別の ADL の平均值}

対象老人の一般的属性別に ADL の平均得点を 検討すると, 統計的に有意な差があった項目は, 年齢，仕事，配偶者との同居，現在の疾患，主観 的健康状態，生活費負担，余暇時間であった。つ 
表 4 IADL の項目別性・年齡別障害頻度

\begin{tabular}{|c|c|c|c|c|c|c|}
\hline \multirow{2}{*}{ 年齢 (歳) } & \multicolumn{3}{|c|}{ 遠方への外出 } & \multicolumn{2}{|c|}{ 崱 } & 物 \\
\hline & 男 性 & 女 性 & 全 体 & 男 性 & 女 性 & 全 体 \\
\hline $60 \sim 69$ & $5(3.3)$ & $6(2.6)$ & $11(2.9)$ & $8(5.2)$ & $8(3.5)$ & $16(4.2)$ \\
\hline $70 \sim 79$ & $8(9.1)$ & $22(15.3)$ & $30(12.9)$ & $9(10.2)$ & $23(16.0)$ & $32(13.8)$ \\
\hline $80 \sim$ & $17(47.2)$ & $31(55.4)$ & $48(52.2)$ & $17(47.2)$ & $32(57.1)$ & $49(53.3)$ \\
\hline 全 体 & $30(10.8)$ & $59(13.8)$ & $89(12.6)$ & $34(12.3)$ & $63(14.7)$ & $97(13.8)$ \\
\hline \multirow{2}{*}{ 年齢 (歳) } & \multicolumn{3}{|c|}{ 食事の用意 } & \multicolumn{3}{|c|}{ 請求書の支払い } \\
\hline & 男 性 & 女 性 & 全 体 & 男 性 & 女 性 & 全 体 \\
\hline $60 \sim 69$ & $11(7.2)$ & $4(1.8)$ & $15(3.9)$ & $7(4.6)$ & $15(6.6)$ & $22(5.8)$ \\
\hline $70 \sim 79$ & $16(18.2)$ & $8(5.6)$ & $24(10.3)$ & $9(10.2)$ & $40(27.8)$ & $49(21.1)$ \\
\hline $80 \sim$ & $22(61.1)$ & $19(33.9)$ & $41(44.6)$ & $20(55.6)$ & $37(66.1)$ & $57(62.0)$ \\
\hline 全 体 & $49(17.7)$ & $31(7.2)$ & $80(11.4)$ & $36(13.0)$ & $92(21.5)$ & $128(18.2)$ \\
\hline \multirow{2}{*}{ 年齢 (歳) } & \multicolumn{3}{|c|}{ 預貯金の管理 } & & & \\
\hline & 男 性 & 女 性 & 全 体 & & & \\
\hline $60 \sim 69$ & $7(4.6)$ & $21(9.2)$ & $28(7.4)$ & & & \\
\hline $70 \sim 79$ & $12(13.6)$ & $48(33.3)$ & $60(25.9)$ & & & \\
\hline $80 \sim$ & $22(61.1)$ & $41(73.2)$ & $63(68.5)$ & & & \\
\hline 全 体 & $41(14.8)$ & $110(25.7)$ & $151(21.4)$ & & & \\
\hline
\end{tabular}

表 5 IADL 評点の性・年齡別頻度

\begin{tabular}{|c|c|c|c|c|c|c|}
\hline \multirow{2}{*}{ 年齢 (歳) } & \multicolumn{2}{|c|}{ 高 $\mathrm{ADL}$} & \multicolumn{2}{|c|}{ 中 ADL } & \multicolumn{2}{|c|}{ 低 ADL } \\
\hline & 男 性 & 女 性 & 男 性 & 女 性 & 男 性 & 女 性 \\
\hline $60 \sim 69$ & $142(92.8)$ & $206(90.4)$ & $6(3.9)$ & $20(.8 .8)$ & $5(3.3)$ & $2(0.9)$ \\
\hline $70 \sim 79$ & $68(77.3)$ & $90(62.5)$ & $13(14.8)$ & $48(33.3)$ & $7(8.0)$ & $6(4.2)$ \\
\hline $80 \sim$ & $11(30.6)$ & $14(25.0)$ & $10(27.8)$ & $25(41.7)$ & $15(41.7)$ & $17(30.4)$ \\
\hline 全 体 & $221(79.8)$ & $310(72.4)$ & $29(10.5)$ & $93(21.8)$ & $27(9.8)$ & $25(5.8)$ \\
\hline
\end{tabular}

まり，年齢は若い方が，仕事はある方が，配偶者 はいる方が, 現在の疾患はない方が, 主観的健康 状態はよい方が, 生活費負担は子供に依存してい る方が，余暇時間は活用している方が，それぞれ ADL を高くする要因になっていた（表 6 ）.

\section{5. 属性別の IADL の平均值}

一般的属性別に IADL の平均得点を比較する と, 統計的に有意な差があった項目は, 年齢, 学 歴，仕事，配偶者との同居，家族構成，現在の疾 患, 主観的健康状態, 生活費負担, 余暇時間, ADL であった。つまり, 年齢は若い方が, 学歴は高学 歴の方が, 仕事はある方が, 配偶者はいる方が,
家族構成は夫婦だけの方が，現在の疾患はない方 が, 主観的健康状態はよい方が, 生活費負担は子 供に依存している方が，余暇時間は活用している 方がそれぞれ IADL が高得点であり, ADLの場 合と同じ傾向であった（表 7 ).

\section{ADL の関連要因}

老人の日常生活動作能力 (ADL) に関与する調 查項目の総合的な関連を明らかにするために, 日 常生活動作能力を目的変数, 各調査項目を説明变 数とする Stepwise 重回帰分析を行った.

説明変数のうち，年齢は連続変数とし，その以 外の変数は, 性 (女性 $=0$, 男性 $=1)$, 学歴 (無 
表 6 一般的属性における $\mathrm{ADL}$ 平均值

\begin{tabular}{|c|c|c|c|c|}
\hline 項 & 区 分 & 平均(標準偏差) & $\mathrm{t}$ or $\mathrm{F}$-値 & P-值 \\
\hline \multirow[t]{2}{*}{ 性別 } & 男 性 & $5.82(0.64)$ & 0.23 & 0.8218 \\
\hline & 女 性 & $5.84(0.66)$ & & \\
\hline \multirow[t]{3}{*}{ 年＼cjkstart秢(葴) } & $60-69$ & $5.91(0.46)$ & 22.34 & 0.0001 \\
\hline & $70-79$ & $5.88(0.47)$ & & \\
\hline & $80-$ & $5.33(1.32)$ & & \\
\hline \multirow[t]{3}{*}{ 学 歴 } & な し & $5.82(0.64)$ & 0.79 & 0.4547 \\
\hline & 小卒 & $5.89(0.59)$ & & \\
\hline & 中卒以上 & $5.78(0.88)$ & & \\
\hline \multirow[t]{3}{*}{ 仕 事 } & 茷 業 & $5.95(0.49)$ & 5.02 & 0.0019 \\
\hline & その他 & $5.93(0.27)$ & & \\
\hline & な し & $5.64(0.97)$ & & \\
\hline \multirow[t]{5}{*}{ 宗 教 } & 仏 教 & $5.83(0.58)$ & 0.40 & 0.8476 \\
\hline & キリスト教 & $5.90(0.76)$ & & \\
\hline & 儒 教 & $5.90(0.40)$ & & \\
\hline & その他 & $6.00(0.00)$ & & \\
\hline & な し & $5.77(0.99)$ & & \\
\hline \multirow[t]{2}{*}{ 配偶者 } & あり & $5.99(0.53)$ & 7.73 & 0.0056 \\
\hline & なし & $5.74(0.78)$ & & \\
\hline \multirow[t]{3}{*}{ 家族構成 } & ひとり慕らし & $5.82(0.72)$ & 0.98 & 0.3744 \\
\hline & 夫婦だけ & $5.88(0.67)$ & & \\
\hline & 子供と同居 & $5.80(0.71)$ & & \\
\hline \multirow[t]{2}{*}{ 現在の疾患 } & な し & $5.93(0.43)$ & -3.87 & 0.0001 \\
\hline & あ る & $5.74(0.86)$ & & \\
\hline \multirow[t]{2}{*}{ 生活浿負担 } & 子 供 & $5.92(0.48)$ & 2.87 & 0.0043 \\
\hline & 自分と子供 & $5.76(0.76)$ & & \\
\hline \multirow[t]{2}{*}{ 余暇時間 } & 活 用 & $5.94(0.29)$ & 2.75 & 0.0064 \\
\hline & 非活用 & $5.81(0.70)$ & & \\
\hline \multirow[t]{2}{*}{ 主観的健康状態 } & よ & $5.98(0.16)$ & 5.04 & 0.0001 \\
\hline & 悪 い & $5.74(0.82)$ & & \\
\hline
\end{tabular}

修学 $=0$, 小学校卒以上 $=1$ ), 仕事 $($ 無 $=0$, 有 $=$ 1 ), 宗教（無 $=0$, 有 $=1$ ）, 配偶者（無 $=0$, 有 $=1$ ), 家族構成(ひとり暮らしと夫婦だけ $=0$, 子供と同居 $=1$ ), 現在の疾患 (ある $=0$ ，なし $=$ 1 ), 生活費負担（自分と子供 $=0$, 子供 $=1$ ), 余暇時間 (活用 $=1$, 非活用 $=0$ ), 主観的健康状 態 $($ よい $=1$, 悪い=0) のダミ一変数として分 析を行った。その結果，年齢，主観的健康状態， 余瑕時間が有意に関連し, ADLに対する説明力は $7.0 \%$ ，重相関係数は0.27であった（表 8 ）。

\section{IADL の関連要因}

同様に，老人の手段的 ADL（IADL）に関与す る調査項目の総合的な関連を明らかにするため に, 手段的 ADL を目的变数, 各調査項目を説明変
数とする Stepwise 重回帰分析を行った。

その結果，年齢，生活費負担，ADL，家族構成， 仕事，余暇時間の要因が有意な関連をもち，その

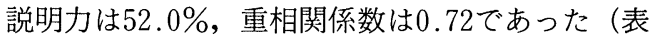
9 ).

\section{V 考察}

病気や死亡に基づく健康指標は，死亡率が高く 平均寿命の短い時代には確かに有用であった。し かし, 高い死亡率がある程度克服され, 人口が高 齢化している社会では，むしろ，生命の量より質 が重視されるようになってきた（柴田ら1979, 1993). 老年期の健康指標としては, 病気や死に目 を向けるのではなく，老人の “自立した生活”や 
表 7 一般的属性における IADL 平均值

\begin{tabular}{|c|c|c|c|c|}
\hline 項 目 & 区 分 & 平均(標準偏差) & $\mathrm{t}$ or $\mathrm{F}$-值 & P-值 \\
\hline \multirow[t]{2}{*}{ 性別 } & 男 性 & $4.31(1.58)$ & -1.20 & 0.2318 \\
\hline & 女 性 & $4.17(1.54)$ & & \\
\hline \multirow[t]{3}{*}{ 年＼cjkstart齢(歳) } & $60-69$ & $4.76(0.89)$ & 141.03 & 0.0001 \\
\hline & $70-79$ & $4.16(1.49)$ & & \\
\hline & $80-$ & $2.20(2.10)$ & & \\
\hline \multirow[t]{3}{*}{ 学 歴 } & な し & $4.02(1.71)$ & 11.39 & 0.0001 \\
\hline & 小 卒 & $4.79(0.81)$ & & \\
\hline & 中卒以上 & $4.67(1.11)$ & & \\
\hline \multirow[t]{3}{*}{ 仕 事 } & 農＼cjkstart業 & $4.75(1.25)$ & 26.66 & 0.0001 \\
\hline & その他 & $5.00(0.00)$ & & \\
\hline & なし & $3.25(1.92)$ & & \\
\hline \multirow[t]{5}{*}{ 宗 教 } & 仏 教 & $4.22(1.55)$ & 0.91 & 0.4895 \\
\hline & キリスト教 & $4.59(1.62)$ & & \\
\hline & 儒 教 & $4.51(1.30)$ & & \\
\hline & その他 & $4.67(0.82)$ & & \\
\hline & な し & $4.00(1.71)$ & & \\
\hline \multirow[t]{2}{*}{ 配偶者 } & あり & $4.55(1.24)$ & 6.18 & 0.0001 \\
\hline & なし & $3.80(1.82)$ & & \\
\hline \multirow[t]{3}{*}{ 家族構成 } & ひとり暮らし & $4.58(1.10)$ & 27.02 & 0.0001 \\
\hline & 夫婦だけ & $4.68(1.05)$ & & \\
\hline & 子供と同居 & $3.82(1.83)$ & & \\
\hline \multirow[t]{2}{*}{ 現在の疾患 } & なし & $4.46(1.34)$ & -3.74 & 0.0002 \\
\hline & ある & $4.03(1.70)$ & & \\
\hline \multirow[t]{2}{*}{ 生活費負担 } & 子 供 & $4.81(0.80)$ & 9.76 & 0.0001 \\
\hline & 自分と子供 & $3.83(1.81)$ & & \\
\hline \multirow[t]{2}{*}{ 余暇時間 } & 活 用 & $4.60(1.11)$ & 3.58 & 0.0004 \\
\hline & 非活用 & $4.16(1.62)$ & & \\
\hline \multirow[t]{2}{*}{ 主観的健康状態 } & よ い & $4.56(1.14)$ & 4.68 & 0.0001 \\
\hline & 悪 い & $4.06(1.71)$ & & \\
\hline \multirow[t]{2}{*}{$\mathrm{ADL}$} & 低中 ADL & $1.98(2.19)$ & 8.94 & 0.0001 \\
\hline & 高 $\mathrm{ADL}$ & $4.45(1.27)$ & & \\
\hline
\end{tabular}

表 8 老人の ADL の関連要因 (Stepwise Multiple Regression)

\begin{tabular}{|c|c|c|c|c|}
\hline 項 & 目 & 偏回帰係数 (標準詔差) & F-值 & p-值 \\
\hline \multicolumn{2}{|l|}{ 年齢 } & $-0.02(0.03)$ & 32.57 & 0.0002 \\
\hline \multicolumn{2}{|c|}{ 主観的健康状態* } & $0.14(0.06)$ & 5.62 & 0.0181 \\
\hline \multicolumn{2}{|c|}{ 余㗇時間** } & $0.14(0.06)$ & 5.99 & 0.0146 \\
\hline \multicolumn{2}{|l|}{ 定数 } & 7.06 & & \\
\hline \multicolumn{2}{|c|}{ 重相関係数 } & $\mathrm{R}=0.27$ & & \\
\hline \multicolumn{2}{|c|}{ 決定係数 } & $\mathrm{R}$-square $=0.07$ & & \\
\hline \multicolumn{2}{|c|}{$\begin{array}{l}{ }^{*} \text { : 主観的健康状態 } \\
\text { * }^{* *} \text { : 余㗇時間 }\end{array}$} & $\begin{aligned} \text { 態 } & \text { (悪い }=0, \text { よい } \\
& \text { (非活用 }=0 \text {, 活 }\end{aligned}$ & 1) & \\
\hline
\end{tabular}

“充実した生活”に焦点をあてた評価が望まれよ う.この視点に立った健康指標が, 活動能力から
見た健康度の指標である(古谷野，1991：藤田ら， 1989：藤田, 1989).

本研究は, 日常生活動作能力 (ADL) と手段的 ADL (IADL) を用いて, 韓国の農村の一行政地区 を対象とした 60 歳以上老人の訪問悉皆調査であ る.

高齢者に対する日常生活動作能力（ADL）と手 段的 ADL (IADL) の調査では, 調査の内的整合 性，信頼性が問題になることがある，我々の調査 も, 調査員が直接老人を家庭訪問して行う質問・ 面接聞き取り調査にあたって，老人の負担を軽減 するために，質問数をなるべく減らすなどの工夫 をした。すなわち，質問項目の内的整合性は 
表 9 老人の IADL の関連要因 (Stepwise Multiple Regression)

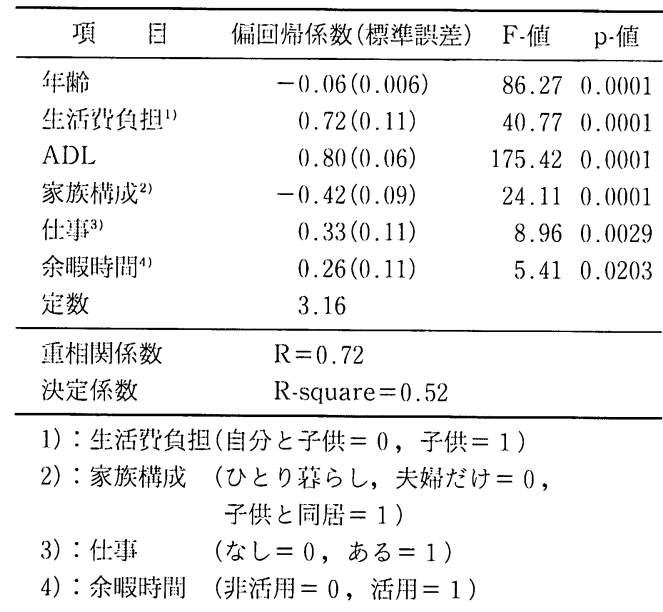

Cronbach's $\alpha$ 係数，信頼性は Test-Retest 法によ りそれぞれ評価した。なお，Test-Retest 法による 信頼性の検討は, 予備調查50例と本調查705例につ いて行った。日常生活動作能力 (ADL) の Cronbach's $\alpha$ 係数 $(=0.844)$, Test-Retest (= 0.891), 手段的 ADL (IADL) の Cronbach's $\alpha$ 係 数 $(=0.883)$, Test-Retest $(=0.864)$ はすべて高 く,内的整合性と信頼性は確認できた. TestRetest 法については, 予備調查対象者50名が本調 查対象705名中に含まれるので繰り返しの効果が 問題となり得るが， 2 週間の間隔があり，記銘力 の乏しい高齢者であるから，この手法は成立する と言えよう。

韓国では地域老人の中に障害者がどの程度存在 しているかを観察した成績は意外に少ない。本調 査地域の在宅高齢者の日常生活動作能力 (ADL) (入浴, 着替え, 歩行, トイレの使用, 食事, 失禁) の完全自立者は $90.8 \%$ であった。性・年齢別にお ける日常生活動作能力 (ADL) 障害頻度を見ると “失禁する”が $6.5 \%$ で番高かった。そして，す べての項目について加齢にともなって障害頻度が 上昇した。性別では “失禁”, “食事” の項目は女 性の方が高く, それ以外の項目は男性の方が高 かった.
山川ら（1994）が，滋賀県安土町の65歳以上の 在宅高齢者全員 1,287 人を対象に行った調査では, 日常生活動作能力（ADL）の完全自立者は $80.6 \%$ であった。そして，性・年齢別の日常生活動作能 力 $(\mathrm{ADL})$ の障害頻度では，“失禁する” $(16.0 \%)$ のみは高かったものの, 他は 2 〜 \%であった。 また，すべての項目で加秢にともなって障害頻度 が上昇し，性別では “失禁” の項目で女性の方が 高かったことだけが認められている。

本調査地域では，在宅高萪者の手段的 ADL (IADL)（遠方への外出, 買い物, 食事の用意, 請 求書の支払い，預貯金の管理）の完全自立者は $75.3 \%$ あった。性・年柃別に手段的 ADL (IADL)の障害頻度を見ると，“預貯金の出し入れ ができない”が21.4\%で一番高く，すべての項目 について加齢にともなって障害頻度が上昇してい た。そして，性別では“自分で食事の用意ができ ない”が男性で $17.7 \%$ ，女性で7.2\%であり，男性 の方が高かったが，それ以外の項目では女性の障 害頻度の方が高かった。

Koyano et al（1988）は，東京都小金井市の65 歳以上の在宅高齢者7.735人から手段的 ADLに 関する情報を得た。彼らの調査でも, “自分で食事 の用意ができない”を除いた他のすべての項目で, 男性の自立度が女性より高いことが示された。男 性で“自分で食事の用意ができない”が高かった 理由としては，家事における伝統的な役割，つま り食事の支度は女性の役割とされており，男性は 若い時からその経験をもたない者が多かったこと によると考えられる，そして，日本の地域老人の 場合もすべての項目について加柃にともなって障 害頻度が高くなっている，各項目について韓国と 日本の差を見ると，“請求書の支払い”と“預貯金 の管理”の項目でそれぞれ日本では $11.3 \%, 16.1 \%$ であるのに対し, 韓国(本研究)では $18.2 \%, 21.4 \%$ と大きな差異が見られた。これは都市と農村によ る差も考えられるが，さらに大きい原因は韓国老 人の場合教育を受けていない割合が $66.1 \% に の$ ぼっており，銀行利用を知らないかその機会を 持ったことのない者が多かったことであろう. 
日本で行われた小林ら（1990）の調査における IADL の分布を見ると, 高 IADL（5点）は男性が $79.2 \%$, 女性が76.7\%であり, 中 IADL ( 1 ～ 4 点) は男性が $14.7 \%$ ，女性が $16.0 \%$ あり，低 IADL （０点）は男性が $6.2 \%$, 女性が7.3\%であるが，本 研究では高 IADL は男性が79.8\%, 女性が72.4\% であり，中 IADL は男性が $10.5 \%$, 女性 $21.7 \%$ で あり，低 IADL は男性が $9.8 \%$, 女性が5.8\%で あったどちらの研究においても性差が見られる が，男性では韓国人で，女性では日本人で IADL の障害が高い傾向が見られたことになる.

対象老人の一般的属性別に ADL の平均得点を 見ると性差はないが，年齢は若い方が，仕事はあ る方が, 配偶者はいる方が, 現在の疾患はない方 が，主観的健康状態はよい方が，生活費負担は子 供に依存している方が, そして, 余暇時間は活用 している方が, ADL 得点が高かった. 対象老人の 一般的属性別に IADL 平均得点を見ても同様の 傾向が認められた。すなわち年齢は若い方が，学 歴は高学歴の方が, 仕事はある方が, 配偶者はい る方が, 家族構成は夫婦だけの方が, 現在の疾患 はない方が, 主観的健康状態はよい方が, 生活負 担は子供に依存している方が, 余暇時間は活用し ている方が，そして ADL は高 ADLの方が， IADL 得点が高かった.

老人の日常生活動作能力 (ADL) に関与してい る要因を総合的に明らかにするために行った Stepwise 重回㷌分析の結果, 年齢, 主観的健康状 態, 余暇時間の要因による ADLの説明力は

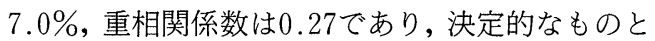
はいえない.

IADL は日常生活動作能力 (ADL) よりも高次 の活動能力とされ, どの項目も ADL が良好であ ることを前提にしている.したがって, IADLが ADLの影響を受けるのは当然である。高齢者にお ける IADL 低下に影響を及ぼす要因としては，年 齢, 生活費負担, $\mathrm{ADL}$, 家族構成, 仕事, 余㗇時 間で，これらの要因によるIADLに対する説明力

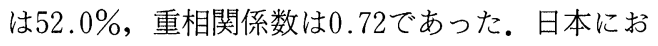
ける Kobayashi et al.（1990）の場合も，ADL,
年齢，仕事，余㗇時間が有意な要因として抽出さ れ，これらの要因による IADL の説明力は 6 割近 くに達し，類似の結果が得られている。

\section{VI まとめ}

韓国の慶尚北道・慶州市の江東面にある27里の うち，1つの保健支所と 1 つの保健診療所が担当 している14里に居住している満60歳以上の在宅老 人 705 人全員を対象にして, 日常生活動作能力 (ADL) と手段的 ADL (IADL) の実態とその関連 要因を分析し，以下の知見を得た。

1) 性・年齢別に日常生活動作能力 (ADL) 障害 頻度を見ると, “失禁する”が $6.5 \%$ で一番高く, すべての項目について加齢にともなって障害頻度 が上昇した．性別では，その頻度は “食事” の項 目で女性の方が低く，それ以外の項目では男性の 方が低い.また，ADL の分布を見ると高 $\operatorname{ADL}(6$ 点）は男性が 250 人 (90.2\%)，女性が390 (91.1\%) であり，低 ADL（0 点）は男性が 1 人 $(0.4 \%)$ ， 女性が 2 人 (0.5\%) であった。

2）手段的日常生活動作能力（IADL）の分布を 見ると，高 IADL（5点）は男性が221人 (79.8\%), 女性が310人 (72.4\%) であり, 低 IADL（ 0 点） は男性が 27 人 $(9.8 \%)$ ，女性が 25 人 $(5.8 \%)$ であっ た。また，性別に見ると“自分で食事の用意がで きない”頻度は男性が $17.7 \%$ （女性は7.2\%）で高 く，それ以外の項目では女性で障害頻度が高かっ た. 年齢別の IADL 障害頻度では, “預貯金の出し 入れができない”が $21.4 \%$ 一番高く, かつすべ ての項目について加齢にともなって障害頻度が上 昇した。

3）対象老人の一般的属性別に ADL 平均得点 を見ると, 統計的に有意な差があった項目は, 年 齢，仕事，配偶者同居の有無，現在の疾患，主観 的健康状態，生活費負担，余暇時間であった。つ まり，年齢は若い方が，仕事はある方が，配偶者 はいる方が, 現在の疾患はない方が, 主観的健康 状態はよい方が，生活費負担は子供に依存してい る方が，余暇時間は活用している方が，それぞれ 得点が高かった。 
4）対象老人の一般的属性別に IADL 平均得点 を見ると，統計的に有意な差があった項目は，年 軨, 学歴, 仕事, 配偶者同居の有無, 家族構成, 現在の疾患，主観的健康状態，生活費負担，余暇 時間， ADLであった。つまり，年齢は若い方が， 学歴は高学歴の方が，仕事はある方が，配偶者は いる方が，家族構成は夫婦だけの方が，現在の疾 患はない方が，主観的健康状態はよい方が，生活 費負担は子供に依存している方が，余暇時間は活 用している方が，ADL は高 ADL の方が，より得 点が高かった。

5）老人の日常生活動作能力（ADL）と手段的 $\mathrm{ADL}$ (IADL)に関連している要因を総合的に明ら かにするために，ADL と IADLを目的変数とし て Stepwise 重回帰分析を行った結果，ADLに影 毸を及ほす要因は年歯，主観的健康状態，余暇時 間であり，同じくIADL では年齿, 生活費負担, ADL，家族構成，仕事，余暇時間であった.

\section{文献}

Fillenbaum, G.G. (1985) : A brief instrumental activities of daily living measure, J. Am. Geriat. Soc., 33, 698-706

藤田利治, 籏野脩一（1989）：地域老人の日常生活動 作の障害とその関連要因，日本公衛誌，36(2), 76-87

藤田利治（1989）：地域老人の日常生活動作能力低下 の生命予後への影響, 日本公衛誌，36(10), 717-729

Katz, S., Downs, T.D., Cash, H.R. \& Grotz, R.C. (1970): Progress in development of the Index of ADL, Gerontologist, 10(1), 20-30

Katz, S., et al. (1983) : Active life expectancy, N. Engl. J. Med., 309, 1218-1224

小林廉毅，甲斐一郎，大井 玄，木内松代子（1990）：
農村地域における高齢者の手段的自立 (Instrumental activities of daily living）とこれに関する要因 の研究, 日本公衛誌, 36(4), 243-249

古谷野亘, 柴田 博, 䓅賀 博, 須山靖男 (1984)：地 域老人に打ける日常生活動作能力。日本公衛誌, 31(12), 637-641

古谷野亘 (1991)：地域老人における手段的 ADL，社 会老年学, 33(1), 56-67.

古谷野亘，柴田 博，中里克治，芳賀 博，須山靖男 (1987）：地域老人における活動能力の測定一老研 式活動能力指標の開発一, 日本公衛誌, 34(3), 109114

Koyano, W., Shibata, H., Nakazato, K., Haga, H. \& Suyama, Y. (1988): Prevalence of disability in instrumental activities of daily living among elderly, Japanese J. Gerontol., 43, S41-S45

Lawton, M.P. \& Brody, E.M. (1969) : Assessment of older people selfmaintaining and instrumental activities of daily living, Gerontol., 9, 179-186

Lawton, M.P. (1972): Assessing the competence of older people. In Kent, DP., et al. (ed.), Research Planning and Action for the Elderly, The Power and Potential of Social Science, 123-143, Behavior Publication, (New York)

柴田 博, 古谷野亘, 芳賀 博 (1979)：ADL 研究の 最近の動向，社会老年学，21(2), 70-83

柴田 博, 芳賀 博, 長田久雄, 古谷野亘 (1993)：老 年学入門, 川島書店（東京）

WHO (1984): The uses of epidemiology in the study of the elderly : Report of a WHO Scientific Group on the epidemiology of Aging, WHO Techical Report Series No 706, (Geneva)

山川正信，上島弘嗣，岡山 明ほか (1994）：訪問悉 皆調査による在宅高柃者の ADL（日常生活動作能 力）の実態，日本公衛誌，41(10), 987-995 (受稿 至急 1997.2.26；受理 1997.6.18) 